\title{
Partial Purification and Characterization of Two Enzymes Involved in Isovaleric Acid Synthesis in Clostridium bifermentans
}

\author{
By M. L. BRITZ AND R. G. WILKINSON* \\ Department of Microbiology, University of Melbourne, Parkville, Victoria 3052, Australia
}

(Received 20 October 1982; revised 14 March 1983)

\begin{abstract}
Conversion of leucine to isovaleric acid by Clostridium bifermentans is achieved by the action of at least two enzymes. One is a transaminase producing $\alpha$-ketoisocaproic acid, which was purified 30 -fold from osmotic lysates of late-exponential phase cells by repeated chromatography on DEAE-Sepharose C16B and Sephacryl S300: this represented a 147-fold purification of activity found in sonically disrupted cells. This enzyme had an apparent molecular weight of approximately 190000 and was composed of six identically sized sub-units (molecular weight $31000 \pm 1000$ ). Transamination required pyridoxal phosphate and pyruvate and was optimal at pH 8.6; the apparent $K_{\mathrm{m}}$ for leucine was $7.0 \mathrm{~mm}$. Activity was totally inhibited by $1 \mathrm{~mm}-p$ chloromercuribenzoate and partially inhibited by other thiol reagents. The second enzyme decarboxylated $\alpha$-ketoisocaproic acid to form isovaleric acid and was also partially purified by chromatography on DEAE-Sepharose C16B and Sephacryl S300. It has an apparent molecular weight of 240000 and required FAD and coenzyme A for activity; the $K_{\mathrm{m}}$ for $\alpha$-ketoisocaproic acid was $4.2 \mathrm{~mm}$ and activity was optimal around $\mathrm{pH} 8 \cdot 0$. This enzyme was a flavoprotein with absorption maxima at 280,320 and $400 \mathrm{~nm}$, and a fluorescent maximum at $500 \mathrm{~nm}$. The prosthetic group, FAD, dissociated from the protein during purification resulting in an inactive apoenzyme which was only partially re-activated by FAD. Activity was completely inhibited by several thiol reagents tested at $1 \mathrm{~mm}$.
\end{abstract}

\section{INTRODUCTION}

Amino acid degradation in many species of anaerobic bacteria is often achieved by a mechanism known as the Stickland reaction, where oxidation and reduction reactions occur between one or more amino acids or non-nitrogenous compounds derived from amino acids (see review by Barker, 1981). Usually, one amino acid functions as a proton donor which is oxidatively deaminated and decarboxylated; reducing power generated in this reaction is consumed during reductive deamination of the amino acid proton acceptor. Although these reactions are of some metabolic significance, as they allow energy production during growth on protein hydrolysates, there have been relatively few studies on the enzymes involved in either the oxidative or reductive branches of this fermentation. Many of the schemes describing the mechanisms of these reactions are devised from data derived from cultural studies and conversion of substrates to products by whole cells. The notable exceptions involve glycine and proline reduction where the enzymes have been extensively purified (Seto \& Stadtman, 1976; Tanaka \& Stadtman, 1979; Turner \& Stadtman, 1973), and oxidation of ornithine (Barker, 1981 ; Jeng et al., 1974).

Leucine had normally been regarded as a proton donor in the Stickland reaction where it is converted to isovaleric acid (iV) (Barker, 1961; Nisman, 1954). However, cultural studies by Elsden \& Hilton (1978) indicated that leucine is also reduced to 4-methylvaleric (isocaproic) acid (iC). We have recently demonstrated (Britz \& Wilkinson, 1982a) that washed cell suspensions of several species of proteolytic clostridia and Peptostreptococcus anaerobius convert leucine to iV

Abbreviations: iC, isocaproic acid; $\alpha \mathrm{kiC}, \alpha$-ketoisocaproic acid; iV, isovaleric acid. 
and $\mathrm{iC}$ within the one reaction whose stoichiometry is compatible with that of the Stickland reaction. Here, leucine acts as both proton donor and acceptor, so providing a unique system for studying the relationships between the oxidative and reductive branches of the Stickland reaction.

Leucine oxidation can be detected in cell-free extracts prepared by osmotic lysis or sonication (Britz \& Wilkinson, 1983). Alternative methods of lysis of Clostridium bifermentans have been used to demonstrate that leucine oxidation is catalysed by at least one soluble enzyme [deaminating leucine to $\alpha$-ketoisocaproic acid $(\alpha \mathrm{kiC})$ ] and one membrane-associated enzyme (decarboxylating $\alpha \mathrm{kiC}$ to iV) (Britz \& Wilkinson, 1983). Both enzymes were solubilized by sonication. Reduction of leucine by this species was closely linked to the oxidative reaction and did not occur if the oxidative reaction was replaced by artificial proton donors such as dimercaptans, which have been used to detect glycine and proline reduction (Seto \& Stadtman, 1976; Turner \& Stadtman, 1973): this activity was also membrane-associated and was lost if cells were disrupted by sonication. Decarboxylase activity was stimulated by at least two dialysable factors (molecular weights $<3500$ ), which were released during osmotic lysis and which were separated from activity when extracts were divided into soluble and particulate components. In addition to these yet unidentified factors, oxidation of leucine to iV required several cofactors including coenzyme A, FAD and pyridoxal phosphate with some dependence on pyruvate and $\mathrm{NAD}^{+}$or $\mathrm{NADP}^{+}$. The oxidative system was sensitive to inhibition by oxygen but could be partially stabilized by reducing reagents. In the present communication, we describe the purification and some of the properties of two enzymes involved in leucine oxidation. This work has been presented in preliminary form (Britz \& Wilkinson, 1982 b).

\section{METHODS}

Organisms, media and growth conditions. Clostridium bifermentans strain MB49 was used throughout this work. Its isolation, identification and conditions of growth have been described previously (Britz \& Wilkinson, 1982a). Late-exponential to early-stationary phase cultures were prepared using a $15 \%(\mathrm{v} / \mathrm{v})$ inoculum from a stationary phase culture into proteose peptone broth pre-reduced in an anaerobic chamber under an atmosphere of $5 \% \mathrm{H}_{2}$, $10 \% \mathrm{CO}_{2}$ and $85 \% \mathrm{~N}_{2}$. Cultures were set up in $400 \mathrm{ml}$ bottles which were sealed in the chamber then removed for incubation at $37^{\circ} \mathrm{C}$ for 3 to $4 \mathrm{~h}$, unshaken.

Preparation of cell-free extracts. Cells were harvested by centrifugation $\left(10000 \mathrm{~g}, 20 \mathrm{~min}, 4^{\circ} \mathrm{C}\right)$ and washed in an equivalent volume of $0.05 \mathrm{M}$-Tris/ $\mathrm{HCl}$ containing $100 \mathrm{mM}-\mathrm{K}_{2} \mathrm{HPO}_{4}$ and $1 \mathrm{mM}-\mathrm{EDTA}$ (TKE buffer, final pH 8.2). For osmotic lysis, cells were subsequently resuspended in $2.5 \%$ of the culture volume in TKE buffer plus $20 \%$ (w/v) sucrose ; lysozyme, when used, was added at $0.5 \mathrm{mg} \mathrm{ml}^{-1}$. The cell suspension was incubated at $37^{\circ} \mathrm{C} \mathrm{for} 10 \mathrm{~min}$, when the cells were collected by centrifugation $\left(3000 \mathrm{~g}, 10 \mathrm{~min}, 22^{\circ} \mathrm{C}\right)$ and the supernatant fluid was discarded. The pellet was rapidly dispersed in an equivalent volume of ice-cold TKE buffer and held at $4{ }^{\circ} \mathrm{C}$ for $30 \mathrm{~min}$. Particulate material was removed by centrifugation $\left(12000 \mathrm{~g}, 30 \mathrm{~min}, 4^{\circ} \mathrm{C}\right.$ ) and the supernatant (osmotic shock fluid) was retained. For preparation of sonic lysates, cells harvested from cultures by centrifugation were resuspended in $2.5 \%$ of the culture volume in PME buffer ( $0.05 \mathrm{M}$-sodium phosphate, pH $7 \cdot 6$, containing $10 \mathrm{mM}-2$ mercaptoethanol) and disrupted using an MSE 500-W ultrasonic disintegrator at $0.76 \mathrm{~mA}$, output 2-3 for $1 \mathrm{~min}$ at $4{ }^{\circ} \mathrm{C}$. Cell debris was removed by centrifugation as above. All buffers were degassed before use and cell-free extracts were held under a head-space of $\mathrm{N}_{2}$.

Assay procedures. Conversion of leucine to $\alpha \mathrm{kiC}$, or $\alpha \mathrm{kiC}$ to $\mathrm{iV}$, was measured in $0.5 \mathrm{ml}$ incubation mixtures containing the following ( $\mu \mathrm{mol}): \mathrm{MgCl}_{2}, 1 \cdot 5 ; \mathrm{K}_{2} \mathrm{HPO}_{4}, 10$; sodium pyruvate, 1 ; ADP and AMP, 2 each; $\mathrm{NAD}^{+}$, $\mathrm{NADP}^{+}, \mathrm{NADH}, \mathrm{FAD}$, pyridoxal phosphate, lipoic acid, $0 \cdot 2$ each; coenzyme A, 0.05. Reaction mixtures were buffered at $\mathrm{pH} 8.2$ using $40 \mathrm{~mm}$-Tris $/ \mathrm{HCl}$ and contained $5 \mu \mathrm{mol}$ of substrate (either leucine or $\alpha \mathrm{kiC}$ ). When assaying partially purified decarboxylase activity, incubation mixtures contained up to $100 \mu \mathrm{l}(0 \cdot 3 \mathrm{mg}$ protein) of crude osmotic shock fluid which had been treated at $100{ }^{\circ} \mathrm{C}$ for $10 \mathrm{~min}$ to inactivate inherent enzyme activities. This provided the small molecular weight factors which stimulated decarboxylase activity. Reactions were started by the addition of crude or partially purified enzyme containing up to $1 \mathrm{mg}$ protein. Tubes were gassed with $\mathrm{N}_{2}$, sealed and incubated for $30 \mathrm{~min}$ (deaminase) or 4 to $6 \mathrm{~h}$ (decarboxylase) at $37^{\circ} \mathrm{C}$. Reactions were terminated by the addition of $0.1 \mathrm{ml}$ of $1.2 \mathrm{M}-\mathrm{HCl}$ (deaminase) or $50 \% \mathrm{H}_{2} \mathrm{SO}_{4}$ (decarboxylase). The amount of iV produced was determined by GLC as described previously (Britz \& Wilkinson, 1982a). $\alpha \mathrm{kiC}$ was measured using an assay based on that described by Taylor \& Jenkins (1966). Reaction mixtures contained $0.6 \mathrm{ml} \mathrm{sample,} 0.9 \mathrm{ml} \mathrm{H}_{2} \mathrm{O}$ and $0.5 \mathrm{ml}$ 2,4-dinitrophenylhydrazine reagent. This reagent contained approximately $15 \mathrm{~mm}$-2,4-dinitrophenylhydrazine in 
$1.2 \mathrm{M}-\mathrm{HCl}$. After $10 \mathrm{~min}$ at room temperature, the hydrazone derivative of $\alpha \mathrm{kiC}$ was extracted into $2.5 \mathrm{ml}$ cyclohexane, shaken for $20 \mathrm{~s}$ and the emulsion was separated by brief centrifugation. The upper phase ( $2 \mathrm{ml})$ was removed to a fresh tube and $0.75 \mathrm{ml} 10 \% \mathrm{Na}_{2} \mathrm{CO}_{3}$ was added, mixed and the emulsion separated by centrifugation. The lower layer $(0.5 \mathrm{ml})$ was removed and $1.0 \mathrm{ml} 1.0 \mathrm{M}-\mathrm{NaOH}$ was added before reading absorbance at $440 \mathrm{~nm}$. Standards contained up to $0.6 \mu \mathrm{mol} \alpha \mathrm{kiC}$. Activity was calculated as the rate of production of $\mathrm{iV}$ or $\alpha \mathrm{kiC}$ in $\mu \mathrm{mol} \mathrm{h}^{-1}$. Effects of inhibitors and $\mathrm{pH}$ on rates of reaction were tested as described previously (Britz \& Wilkinson, 1982a).

Pyridoxal phosphate was assayed using the method of Wada \& Snell (1961). Phenylhydrazine hydrochloride was prepared by neutralizing $10 \mathrm{ml}$ phenylhydrazine with $6 \mathrm{M}-\mathrm{HCl}$, collecting the precipitate by filtration, washing with diethyl ether and drying under vacuum.

Protein was determined by the Lowry method using crystalline bovine serum albumin as standard, or from absorbance at $280 \mathrm{~nm}$.

Gel chromatography. Sephacryl S200 and S300 (Pharmacia) columns $\left(2.5\right.$ by $45 \mathrm{~cm}$ ) were equilibrated at $4^{\circ} \mathrm{C}$ in PME buffer. Fractions $(2.4 \mathrm{ml})$ were collected at $36 \mathrm{ml} \mathrm{h}^{-1}$. Ion-exchange chromatography was performed using two successive columns of DEAE-Sepharose C16B (Pharmacia), the first $1.6 \times 45 \mathrm{~cm}$ and the second $1.2 \times 30 \mathrm{~cm}$. Both were initially equilibrated at $4{ }^{\circ} \mathrm{C}$ in PME buffer and $6 \mathrm{ml}$ or $3 \mathrm{ml}$ fractions were collected at $50 \mathrm{ml} \mathrm{h}^{-1}$.

$P A G E$. Electrophoresis was performed according to the methods of Weber \& Osborn (1969) or Laemmli (1970). Non-denaturing slab gels contained $6 \%(\mathrm{w} / \mathrm{v})$ acrylamide and denaturing (SDS) gels contained 7.5\% (w/v) acrylamide; stacking gels contained $3 \%(\mathrm{w} / \mathrm{v})$ acrylamide. Samples contained up to $75 \mu \mathrm{g}$ protein in $50 \mu \mathrm{l}$, and $10 \mu \mathrm{g}$ of each standard protein was applied. Samples were applied to the gel using $10 \mathrm{~mA}$ and subsequently run at $28 \mathrm{~mA}$ at room temperature. Proteins were stained with $0.1 \%$ Coomassie brilliant blue in methanol/acetic acid/water $\left(5: 1: 5\right.$, by vol.) for $10 \mathrm{~min}$ at $60{ }^{\circ} \mathrm{C}$ then initially destained for $1 \mathrm{~h}$ in $5 \%$ acetic acid and $7.5 \%$ methanol, at $60{ }^{\circ} \mathrm{C}$. For determination of native molecular weights of proteins the following standards were used: apoferritin (450000), catalase (240000), bovine serum albumin (67000), ovalbumin (43000), $\beta$-lactoglobulin (36500), trypsin inhibitor (soy bean) (21500) and cytochrome $c$ (12400).

Purification of enzymes. Cells from 41 were pelleted, washed in TKE buffer then subjected to the osmotic shock procedure described above. Shock fluids were filtered $(0.45 \mu \mathrm{m}$ pore size, Millipore), yielding about $100 \mathrm{ml}$ extract, containing 2 to $5 \mathrm{mg}$ protein $\mathrm{ml}^{-1}$, then applied to the first DEAE-Sepharose C16B column. After washing the gel with $200 \mathrm{ml}$ PME buffer, a linear gradient of 0 to $0.5 \mathrm{M}-\mathrm{NaCl}$ in $600 \mathrm{ml} \mathrm{PME}$ buffer was applied. Fractions exhibiting deaminating activity were pooled, concentrated by ultrafiltration (PM 10 membrane, Amicon), then applied to a column of Sephacryl S300. Pooled active fractions were applied to the second DEAESepharose C16B column, the gel was washed with $120 \mathrm{ml}$ PME buffer and then eluted using a $300 \mathrm{ml}$ linear gradient of 0 to $0.25 \mathrm{M}-\mathrm{NaCl}$. Active fractions were analysed by non-denaturing PAGE and selected fractions pooled. This material was concentrated by collodion finger to $3 \mathrm{ml}$ and reapplied to the Sephacryl S300 column. After concentration (three- to fivefold), fractions were analysed by non-denaturing and denaturing PAGE.

Decarboxylase activity was partially purified from an extract of sonically disrupted cells from 41 of culture prepared as described above. Extracts $\left(50 \mathrm{ml}\right.$, containing 10 to $15 \mathrm{mg}$ protein $\mathrm{ml}^{-1}$ ) were applied to the first DEAE-Sepharose C16B column, washed with $300 \mathrm{ml}$ PME buffer containing $0 \cdot 1 \mathrm{M}-\mathrm{NaCl}$, then eluted using a linear gradient of 0.1 to $0.4 \mathrm{M}-\mathrm{NaCl}$ in $600 \mathrm{ml} \mathrm{PME}$ buffer. Active fractions were pooled, diluted twofold in PME buffer and applied to the second DEAE column. This gel was washed with $120 \mathrm{ml}$ PME buffer containing $0 \cdot 1 \mathrm{M}-$ $\mathrm{NaCl}$ and then a $300 \mathrm{ml}$ linear gradient of $0 \cdot 1$ to $0.25 \mathrm{M}-\mathrm{NaCl}$ was applied. Active fractions were pooled and concentrated by collodion finger to $3 \mathrm{ml}$ and applied to the Sephacryl S300 column. Decarboxylase activity, absorbance at 280,400 and $450 \mathrm{~nm}$ and fluorescence were measured in all fractions.

Analytical procedures. Spectrophotometric measurements were made on a Zeiss PMQ II spectrophotometer and fluorescence readings on an Aminco Bowman Spectrophotofluorimeter (American Instrument Co.) in cells with $1 \mathrm{~cm}$ light paths. FAD was measured from fluorescence at $530 \mathrm{~nm}$ (excitation at $445 \mathrm{~nm}$ ) using $0 \cdot 1$ or $0 \cdot 01 \mathrm{~mm}$ standard solutions in appropriate buffers. When reading fluorescence on protein-containing samples, these were treated with $1 \mathrm{mg}$ trypsin $\mathrm{ml}^{-1}$ for $30 \mathrm{~min}$ at $37^{\circ} \mathrm{C}$, then boiled for $10 \mathrm{~min}$ and the precipitated protein removed by centrifugation $(3000 \mathrm{~g}, 10 \mathrm{~min})$. Samples were also deproteinated using trichloroacetic acid, as described by Koziol (1971). To convert FAD to FMN, samples and controls were treated with phosphodiesterase (50 units, $37^{\circ} \mathrm{C}, 1 \mathrm{~h}$ ) then protein was removed as above. The $\mathrm{pH}$ was adjusted using $0.6 \mathrm{M}-\mathrm{HCl}$ to $7 \cdot 3$ and to $2 \cdot 7$ to $3 \cdot 0$, and fluorescence at these $\mathrm{pH}$ values was recorded. Ammonium ion concentrations were measured using an ammonium ion electrode (detecting as little as 1 p.p.m.) as described previously (Britz \& Wilkinson, 1982a).

Chemicals. All substrates, cofactors and proteins used for molecular weight calibrations (with the exception of bovine serum albumin) were obtained from Sigma; bovine serum albumin was from the Commonwealth Serum Laboratories, Australia. Phosphodiesterase (mixed types I and II, Crotalid viper venom) was purchased from Calbiochem, and p-chloromercuribenzoate from BDH. 2,4-Dinitrophenylhydrazine was purchased from Ajax Chemicals (Melbourne, Australia). All other chemicals were of analytical grade and purchased from standard commercial sources. 


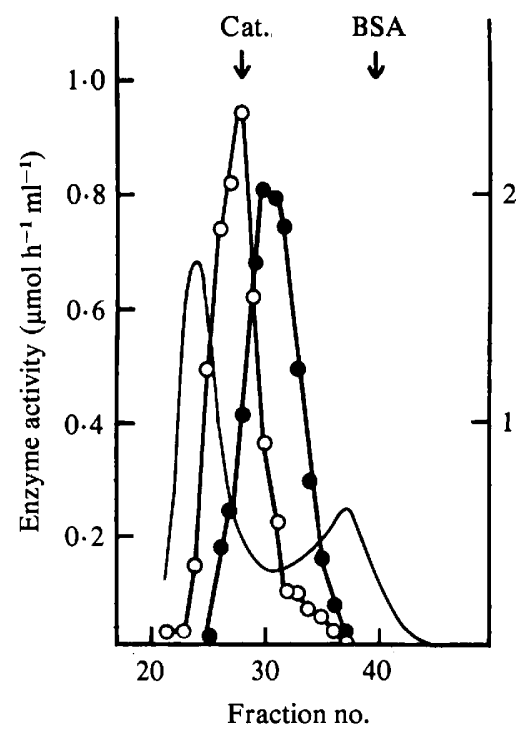

Fig. 1

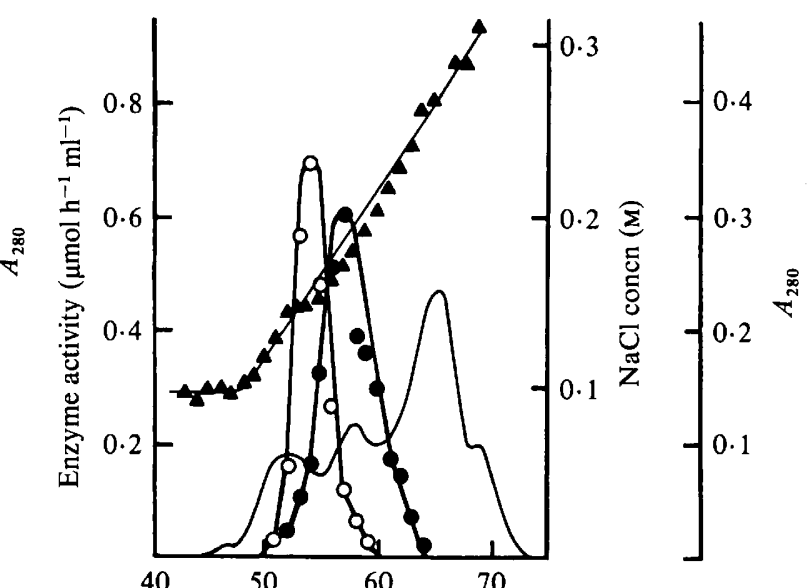

Fraction no.

Fig. 2

Fig. 1. Separation of leucine deaminase and decarboxylase activities by gel filtration through Sephacryl S200. Composite diagram showing the relative elution of deaminase activity originating in osmotic shock fluid and decarboxylase activity from an extract prepared by sonication. $O$, Decarboxylase activity assayed in the presence of heated osmotic shock fluid;,$- A_{280}$ for the osmotic lysate; , deaminase activity. Two $\mathrm{ml}$ of extracts were applied to the column, equilibrated at $4{ }^{\circ} \mathrm{C}$ in PME buffer and fractionated as described in Methods. The elution volumes of the relevant molecular weight markers catalase (Cat.) and bovine serum albumin (BSA) are indicated.

Fig. 2. Separation of leucine deaminase and decarboxylase activities by ion-exchange chromatography on DEAE-Sepharose C16B. Composite diagram showing the relative positions of leucine deaminase and decarboxylase activities eluting from DEAE-Sepharose C16B. Extracts were prepared from the same culture then separately applied to the gel equilibrated initially in PME buffer at $4{ }^{\circ} \mathrm{C}$. The gel was washed with PME containing $0.1 \mathrm{M}-\mathrm{NaCl}$ until $A_{280}$ was negligible, then a gradient of 0.1 to $0.5 \mathrm{M}-$ $\mathrm{NaCl}$ in PME buffer (total volume $600 \mathrm{ml}$ ) was applied. The column was fractionated as described in Methods and decarboxylase activity was assayed in the presence of heat-inactivated osmotic shock fluid. $\mathrm{NaCl}$ concentrations were determined from conductivity readings. Deaminase; $O$, decarboxylase; $\triangle, \mathrm{NaCl}$ concentration; - $A_{280}$ for the fractionation of the osmotic shock fluid.

\section{RESULTS}

\section{Separation of deaminating and decarboxylating activities by gel chromatography}

Cell free extracts of $C$. bifermentans strain MB49 prepared by sonication contained enzymes which converted leucine to $\alpha \mathrm{kiC}$ and $\alpha \mathrm{kiC}$ to iV (Britz \& Wilkinson, 1983). When sonic extracts were applied to Sephacryl S200 or DEAE-Sepharose C16B, decarboxylating and deaminating activities were poorly separated (Figs 1 and 2). Hence deaminase was purified from osmotic shock fluid which lacked significant decarboxylase activity and had a higher specific activity for deamination than sonic lysates. The apparent molecular weight of the deaminase was approximately 190000 and that of the decarboxylase was approximately 240000 as determined by gel filtration on calibrated Sephacryl S200 and S300 columns.

\section{Partial purification and properties of decarboxylase activity}

Decarboxylase activity was partially purified by chromatography on two DEAE-Sepharose $\mathrm{C} 16 \mathrm{~B}$ columns $(\mathrm{NaCl}$ gradients, $0 \cdot 1$ to $0.4 \mathrm{M}$ and $0 \cdot 1$ to $0 \cdot 25 \mathrm{M}$ ), then on Sephacryl S300. However, recovery from these columns was poor (usually $<50 \%$ of applied activity was recovered at each step) possibly due to the instability of the enzyme, which was related to oxygen sensitivity and uncoupling of a chromogenic prosthetic group. Activity from the first DEAESepharose column eluted in a single peak coincident with a fluorescent chromophore absorbing maximally at $400 \mathrm{~nm}$ (see below). Tubes containing maximum activity were pooled, applied to 


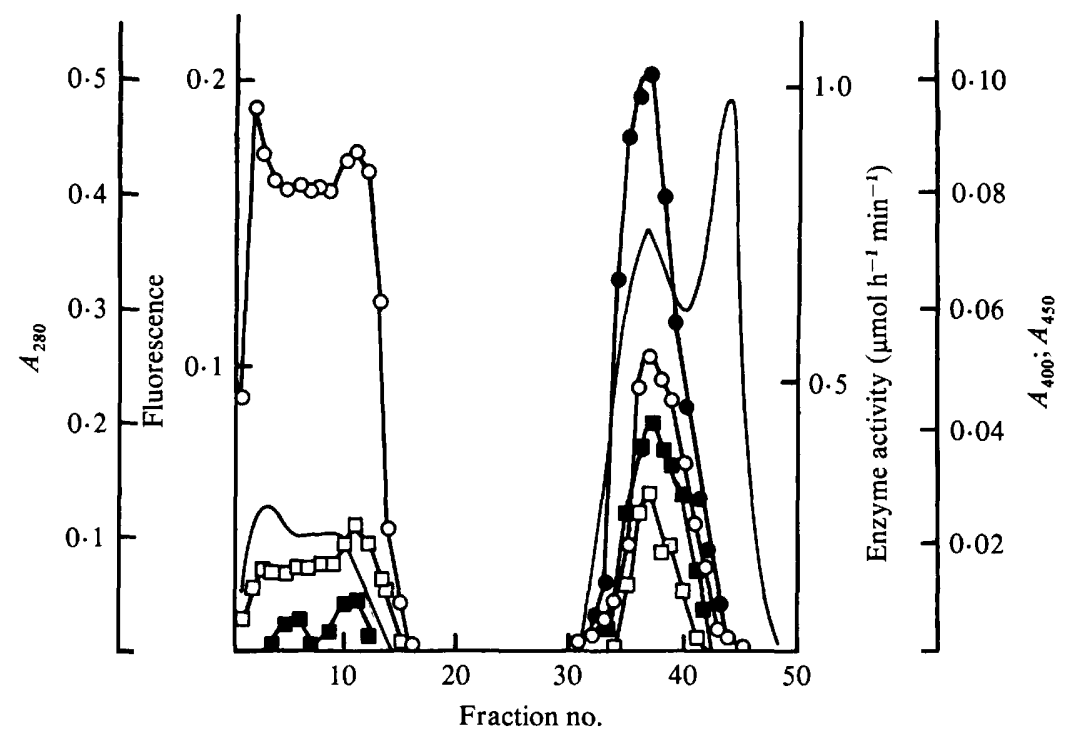

Fig. 3. Relationship between fluorescence and decarboxylase activity. Cells from a 41 proteose peptone broth culture were disrupted by sonication and the cleared extract in PME buffer was applied to a column of DEAE-Sepharose $(1.6 \times 45 \mathrm{~cm})$ equilibrated in PME buffer. After washing and fractionating using a gradient of 0.1 to $0.4 \mathrm{M}-\mathrm{NaCl}(600 \mathrm{ml})$, as described in Methods, the fractions containing decarboxylase activity were pooled and diluted in PME buffer then applied to a second column of DEAE-Sepharose $(1.2 \times 30 \mathrm{~cm})$ equilibrated in PME buffer. The gel was washed using $100 \mathrm{ml}$ PME buffer containing $0 \cdot 1 \mathrm{M}-\mathrm{NaCl}$, then a gradient of $\mathrm{NaCl}$ was applied from $0 \cdot 1$ to $0 \cdot 25 \mathrm{M}$ in a total volume of $300 \mathrm{ml}$ : the start of the gradient corresponds to fraction 25 . Decarboxylase activity (O) was assayed in the presence of heat-inactivated osmotic shock fluid. The following readings were recorded for each fraction: fluorescence detected at $500 \mathrm{~nm}(O) ; A_{280}(-) ; A_{400}(\square) ; A_{450}(\square)$.

the second DEAE-Sepharose column and eluted as described in Methods (Fig. 3). Activity eluted during the 0.1 to $0.25 \mathrm{M}-\mathrm{NaCl}$ gradient in a single peak which was coincident with a peak of protein, fluorescence, and absorbance at $400 \mathrm{~nm}$ : absorption at $400 \mathrm{~nm}$ was greater than that at $450 \mathrm{~nm}$. A small amount of protein was eluted during washing with $0 \cdot 1 \mathrm{M}-\mathrm{NaCl}$, as was a large peak of fluorescent material which absorbed at $450 \mathrm{~nm}$ : absorption at $400 \mathrm{~nm}$ was less than that at $450 \mathrm{~nm}$. This material was not retained during dialysis. Active fractions were pooled, concentrated by collodion finger and applied to Sephacryl S300; the chromophore was proteinassociated during concentration and the effluent had no detectable absorption at 400 or $450 \mathrm{~nm}$. Activity eluted from Sephacryl S300 in a single peak coincident with a peak of fluorescence (profile not shown). However, there was insufficient activity remaining at this stage to allow further purification, so that sub-unit structure of this enzyme was not determined.

The association between decarboxylase activity and a fluorescent chromophore absorbing at $400 \mathrm{~nm}$ suggested that this enzyme may be a flavoprotein. The absorption profile for decarboxylase activity eluting from the final Sephacryl S300 column is shown in Fig. 4. Absorption maxima occurred at 400, 320 and $280 \mathrm{~nm}$. FAD and material washing through the second DEAE-Sepharose column absorbed at 450 and $380 \mathrm{~nm}$. The fluorescence maximum for decarboxylase activity was $500 \mathrm{~nm}$ as compared with $530 \mathrm{~nm}$ for FAD (Fig. 5). Atomic absorption spectroscopy failed to detect iron in excess of levels found in buffer controls. However, the iron levels expected in the samples tested were at the limits of sensitivity for detection $\left(>1.0 \mathrm{mg} \mathrm{l}^{-1}\right)$. Pyridoxal phosphate was not detected in association with this enzyme.

To prove that the prosthetic group was FAD, samples from the final Sephacryl S300 column were deproteinated either by trypsin or trichloroacetic acid treatment (Koziol, 1971) and fluorescence was read after adjusting the $\mathrm{pH}$ to approximately 3.0 or to $7 \cdot 3$ : FAD has a fluorescence maximum at the lower $\mathrm{pH}$, whereas $\mathrm{FMN}$ has almost equal fluorescence intensity over a broad $\mathrm{pH}$ range and has greater fluorescence than FAD. FAD was converted to FMN by 


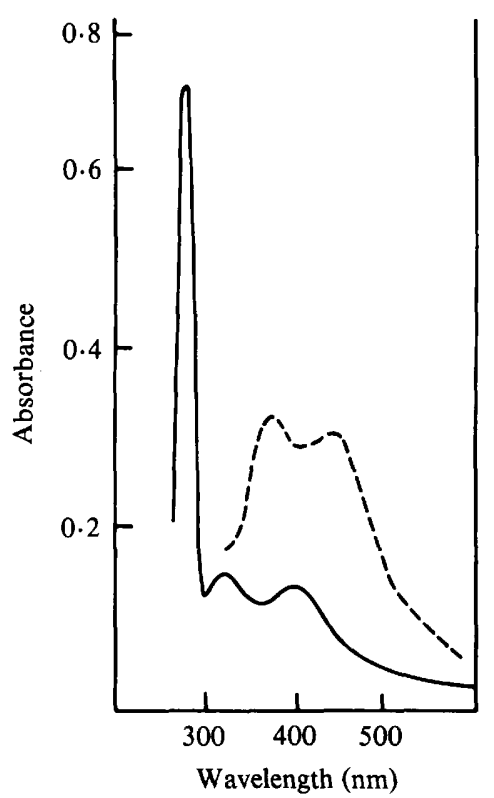

Fig. 4

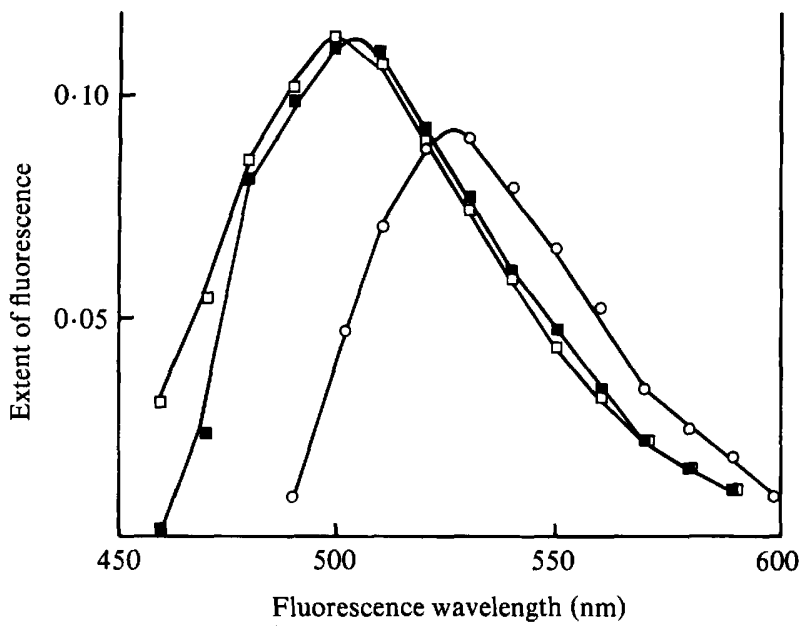

Fig. 5

Fig. 4. Comparison of absorbance spectra for decarboxylase $(-)$ and FAD (---). Decarboxylase activity was partially purified by ion-exchange chromatography on DEAE-Sepharose C16B, eluted firstly using a $\mathrm{NaCl}$ gradient of $0 \cdot 1$ to $0.5 \mathrm{M}$, then applied to a second column and eluted with a gradient of 0.1 to $0 \cdot 25 \mathrm{M}-\mathrm{NaCl}$. The pooled active fractions were concentrated by collodion finger and applied to Sephacryl S300. Absorbance at 260 to $600 \mathrm{~nm}$ was determined using material from fractions containing maximum activity, concentrating threefold by collodion finger.

Fig. 5. Fluorescence maximum for decarboxylase activity, with excitation at $445 \mathrm{~nm}(\square)$ and $400 \mathrm{~nm}$ ( $\square)$. FAD (0.01 mM) in PME buffer (O) was used as a control with excitation at $445 \mathrm{~nm}$. Decarboxylase activity was purified and concentrated as described in the legend to Fig. 4.

\section{Table 1. Identification of the chromophore associated with decarboxylase as FAD}

Fluorescence at high and low $\mathrm{pH}$ values was measured for crude osmotic shock fluid and partially purified enzyme from the final stage of purification, following four types of treatment: no enzyme treatments; deproteinated using trypsin; deproteinated using trypsin, then phosphodiesterase-treated; phosphodiesterase treatment only. FAD was treated similarly. As there was little difference in fluorescence before and after trypsin treatment, selected results only are given.

\section{Sample}

Purified enzyme

FAD $(0 \cdot 1 \mathrm{~mm})$

Crude osmotic shock fluid

FAD + crude osmotic shock fluid

Wash from 2nd DEAE column

$\begin{array}{cc}\text { pH } 7.3 & \text { pH } 3.0 \\ 0.015 & 0.023 \\ 0.015 & 0.024 \\ 0.043 & 0.036 \\ 2.43 & 9.30 \\ 15.39 & 12.30 \\ 0.562 & 0.655 \\ 0.785 & 0.600 \\ 3.75 & 8.80 \\ 9.45 & 9.20 \\ 2.90 & 2.65 \\ 3.00 & 2.79\end{array}$

Ratio of fluorescence $\mathrm{pH} \mathrm{3 \cdot 0/pH} 7 \cdot 3$
$1 \cdot 5$
$1 \cdot 6$
0.8
$3 \cdot 8$
$0 \cdot 8$
$1 \cdot 2$
0.8
$2 \cdot 3$
0.9
0.9
0.9

phosphodiesterase, then fluorescence at different $\mathrm{pH}$ values was determined. Samples of purified enzyme and crude osmotic shock fluid were treated similarly, with and without deproteination. Results following trypsin or TCA treatments were identical and those for the 
Table 2. Cofactor requirements of leucine deaminase and decarboxylase activities

Enzymes were partially purified from osmotic or sonic lysates by ion-exchange chromatography on DEAE-Sepharose.

\section{Omitted cofactor}

$\mathrm{K}_{2} \mathrm{HPO}_{4}$

$\mathrm{MgCl}_{2}$

ADP

AMP

ADP + AMP

Pyruvate

Coenzyme A

Pyruvate + Coenzyme A

NAD ${ }^{+}$

NADH

$\mathrm{NADP}^{+}$

$\mathrm{NAD}^{+}+$NADH

$\mathrm{NAD}^{+}+\mathrm{NADP}^{+}$

$\mathrm{NAD}^{+}, \mathrm{NADH}+\mathrm{NADP}^{+}$

FAD

Lipoic acid

Pyridoxal phosphate

\begin{tabular}{cc}
\multicolumn{2}{c}{ Enzyme activity* } \\
Leucine $\rightarrow \alpha$ kiC & $\alpha$ kiC $\rightarrow$ iV $\dagger$ \\
85 & 100 \\
99 & 96 \\
108 & 109 \\
89 & 112 \\
90 & 88 \\
45 & 115 \\
64 & 22 \\
32 & 17 \\
62 & 114 \\
116 & 108 \\
116 & 124 \\
32 & 130 \\
$N T$ & 110 \\
50 & 122 \\
54 & 13 \\
132 & 109 \\
17 & 95
\end{tabular}

NT, Not tested.

* Percentage of activity found in assays containing all cofactors. Data were obtained from duplicates which showed $10 \%$ variation between assays.

$\dagger$ Assayed in the presence of osmotic lysate.

Table 3. Effects of potential inhibitors on partially purified leucine deaminase and decarboxylase activities

\begin{tabular}{lccc}
\multicolumn{1}{c}{$\begin{array}{c}\text { Concn } \\
\text { Inhibitor }\end{array}$} & $\overbrace{\text { Leucine } \rightarrow \alpha \mathrm{kiC}}$ & $\alpha \mathrm{kiC} \rightarrow \mathrm{iV}$ \\
Iodoacetate & 2 & 47 & 91 \\
Azide & 10 & 0 & 91 \\
Ferricyanide & 1 & 45 & 95 \\
Cyanide & 1 & 0 & 55 \\
Arsenite & 1 & 30 & 81 \\
Arsenate & 1 & 0 & 9 \\
Phenosafranine & 1 & 16 & 0 \\
Neutral red & 1 & 0 & 16 \\
Methyl viologen & 1 & 6 & 24 \\
Methylene blue & 1 & 6 & 0 \\
Metronidazole & 1 & 0 & 0 \\
2,4-Dinitrophenol & 2 & 49 & 84 \\
$p$-Chloromercuribenzoate & $0 \cdot 1$ & 42 & 45 \\
$p$-Chloromercuribenzoate & 1 & 96 & 95
\end{tabular}

* Percentage of inhibition relative to incubation mixtures lacking inhibitors.

former are presented in Table 1. These results are consistent with the prosthetic group being FAD. However, fluorescence of FAD at $\mathrm{pH} 3.0$ was 3.8 times that at $\mathrm{pH} 7.3$, whereas the enzyme was only 1.6 times more fluorescent at $\mathrm{pH} 3.0$ than at $\mathrm{pH} \mathrm{7.3.} \mathrm{This} \mathrm{lower} \mathrm{ratio} \mathrm{for} \mathrm{the}$ enzyme may have been due to partial conversion of FAD to FMN during storage or due to quenching; FAD showed some decrease in this ratio when trypsin-treated in the presence of osmotic shock fluid. The fluorescent material which washed through the second DEAESepharose column, and which had been stored at $4{ }^{\circ} \mathrm{C}$ before testing, had the same fluorescence 


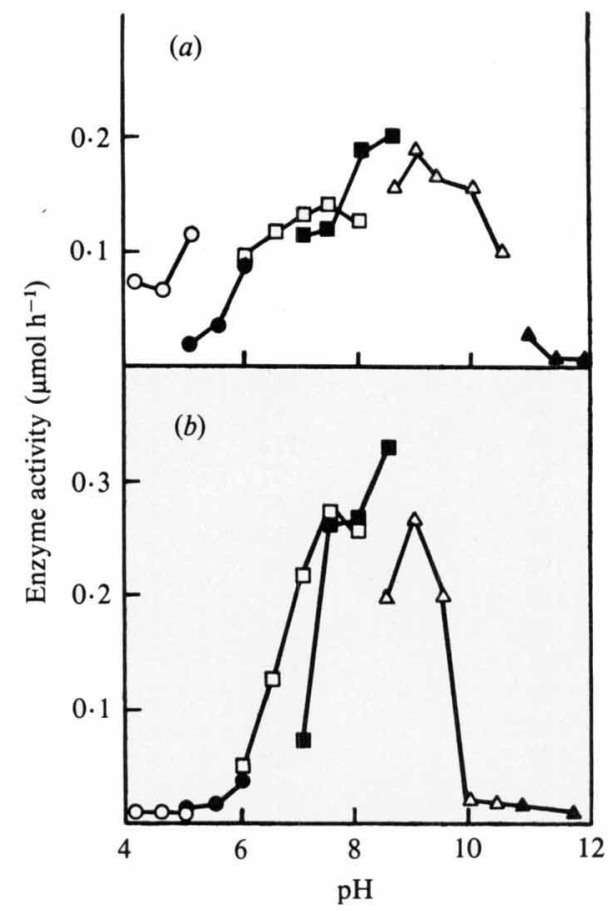

Fig. 6

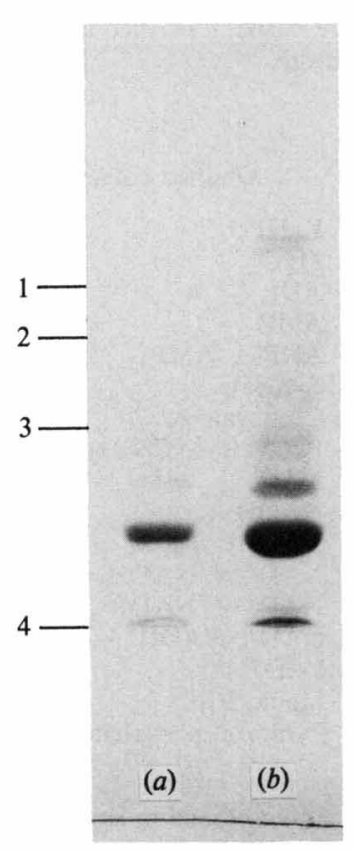

Fig. 7

Fig. 6. $\mathrm{pH}$ optima for assay of leucine deaminase $(a)$ and decarboxylase $(b)$ activities. Enzymes were partially purified by DEAE-Sepharose C16B chromatography, then activity was determined in the following buffers; $0.1 \mathrm{M}$-acetic/acetate $(\mathrm{O}) ; 0.05 \mathrm{M}$-citrate $/ 0 \cdot 1 \mathrm{M}$-phosphate $(\mathrm{O}) ; 0.1 \mathrm{M}$-sodium phosphate $(\square) ; 0.1 \mathrm{M}$-Tris/HCl $(\square) ; 0.1 \mathrm{M}$-glycine $/ \mathrm{NaOH}(\triangle) ; 0.15 \mathrm{M}$-phosphate $/ \mathrm{NaOH}(\boldsymbol{\Delta})$.

Fig. 7. Denaturing PAGE of partially purified leucine deaminase following rechromatography on Sephacryl S300 (Table 4). (a) $10 \mu \mathrm{g}$ protein; (b) $75 \mu \mathrm{g}$ protein. Molecular weight markers : bovine serum albumin (1); catalase (2); ovalbumin (3); cytochrome $c$ (4).

Table 4. Purification of leucine deaminase activity

Details of the experimental procedures are given in Methods.

\begin{tabular}{|c|c|c|c|c|c|c|}
\hline raction & $\begin{array}{l}\text { Volume } \\
\text { (ml) }\end{array}$ & $\begin{array}{c}\text { Total } \\
\text { activity } \\
\text { (units) }\end{array}$ & $\begin{array}{c}\text { Total } \\
\text { protein } \\
(\mathrm{mg})\end{array}$ & $\begin{array}{c}\text { Specific } \\
\text { activity } \\
\text { (units } \mathrm{mg}^{-1} \text { ) }\end{array}$ & $\begin{array}{l}\text { Percentage } \\
\text { recovery }\end{array}$ & $\begin{array}{l}\text { Purification } \\
\text { (fold) }\end{array}$ \\
\hline
\end{tabular}

Crude sonic lysate

Crude osmotic lysate

First DEAE-Sepharose

First Sephacryl S300

Second DEAE-Sepharose

(mg)

(units $\mathrm{mg}^{-1}$ )

recovery

(fold)

Second Sephacryl S300

$\begin{array}{rc}100 & 248 \\ 60 & 209 \\ 35 & 138 \\ 37 & 79 \cdot 4 \\ 25 & 55 \cdot 6\end{array}$

321

$62 \cdot 4$

$20 \cdot 9$

0.156

$0 \cdot 773$

$3 \cdot 35$

$6 \cdot 60$

$5 \cdot 68$

$13 \cdot 9$

$23 \cdot 0$

$\begin{array}{cc}100 & 1 \\ 84 & 4 \cdot 3 \\ 56 & 8 \cdot 5 \\ 32 & 18 \\ 22 & 30\end{array}$

before and after phosphodiesterase treatment and was likely to be FMN. Attempts to stabilize decarboxylase activity by running columns in PME buffers containing FAD did not improve recoveries.

Decarboxylase activity required coenzyme A and FAD (Table 2) and was significantly inhibited by iodoacetate, azide, ferricyanide, arsenite, 2,4-dinitrophenol and $p$-chloromercuribenzoate (Table 3 ). The enzyme was active over a broad $\mathrm{pH}$ range with maximum activity between 7.8 and 8.6 (Fig. 6). The apparent $K_{\mathrm{m}}$ for conversion of $\alpha \mathrm{kiC}$ to iV was $4.2 \mathrm{mM}$. 


\section{Purification and properties of deaminating activity}

The enzyme converting leucine to $\alpha \mathrm{kiC}$ was purified 30 -fold from osmotic shock fluid by repeated chromatography on DEAE-Sepharose C16B and Sephacryl S300 (Table 4). Activity eluted from the final column in a single peak coincident with a protein peak, and analyses by non-denaturing PAGE revealed one major protein band corresponding to activity detected following elution from these gels. Denaturing PAGE showed that the enzyme was probably composed of one type of sub-unit with a molecular weight of approximately 32000 (Fig. 7). This suggests that the enzyme is a hexameric protein, as the apparent molecular weight of the native protein was 190000 as determined by gel filtration. The purified protein did not absorb in the visible region and pyridoxal phosphate was not found in association with the protein purified under these conditions.

Deaminating activity in partially purified preparations required pyridoxal phosphate for activity (Table 2). Although there appears to be some requirement for $\mathrm{NAD}^{+}, \mathrm{NADH}$ or $\mathrm{NADP}^{+}$, omitting all of these did not eliminate activity. Omitting pyruvate, especially in the absence of coenzyme A, decreased activity, whereas lipoic acid appeared to inhibit activity to some extent.

Activity was also partially inhibited by iodoacetate, ferricyanide, arsenite and 2,4dinitrophenol, and significantly inhibited by $p$-chloromercuribenzoate (Table 3 ). The $\mathrm{pH}$ profile for the activity was similar to that for the decarboxylase (Fig. 6). The apparent $K_{\mathrm{m}}$ for conversion of leucine to $\alpha \mathrm{kiC}$ was $7.0 \mathrm{~mm}$.

To determine if the conversion of leucine to $\alpha \mathrm{kiC}$ proceeded by oxidative deamination (yielding free ammonium ions) or transamination (using pyruvate as the $\mathrm{NH}_{4}^{+}$receiving keto acid), ammonium ion levels were measured following incubation of leucine in the presence of purified enzyme and its required cofactors. Although $1.34 \mu \mathrm{mol} \alpha \mathrm{kiC} \mathrm{ml}^{-1}$ was formed after several hours incubation, free ammonium ions were not detected in levels above those of the controls (including heat-inactivated enzyme and enzyme incubated in the presence of leucine but without cofactors).

\section{DISCUSSION}

Early schemes describing the mechanism of the Stickland reaction did not make it clear whether the oxidative branch of the reactions involved transamination or oxidative deamination (Barker, 1961; Nisman, 1954). More recently, Bader et al. (1982) suggested that the initial reaction is a transamination involving $\alpha$-ketoglutarate, which is regenerated by the action of glutamate dehydrogenase. This scheme proposes that the reductive branch of the Stickland reaction is coupled to the oxidative branch, forming an $\alpha$-keto acid by transamination, which is then hydrogenated to form the $\alpha$-hydroxy acid (hence consuming one equivalent of NADH formed by glutamate dehydrogenase). Dehydration of the $\alpha$-hydroxy acid to form an enoate and subsequent hydrogenation of the enoate (catalysed by enoate reductase, consuming a second equivalent of NADH) leads to formation of the aliphatic acid. All of the enzymes involved in this scheme have been demonstrated in crude extracts of several species of proteolytic anaerobes (Bader et al., 1982; Nisman, 1954) or have been purified, in the case of enoate reductase (Bühler et al., 1980). Our results indicate that transamination is the initial step in leucine dissimilation in C. bifermentans. The enzyme purified from osmotic lysates of strain MB49 required pyridoxal phosphate for activity and was probably a hexamer of similar sized sub-units. Production of $\alpha-$ $\mathrm{kiC}$ was not associated with production of free ammonium ions. There was no absolute requirement for $\mathrm{NAD}^{+}$(or $\mathrm{NADP}^{+}$) for reactions catalysed by partially purified enzyme, although activity was less in the absence of all of $\mathrm{NAD}^{+}, \mathrm{NADH}$ and NADP ${ }^{+}$. The reaction was dependent on added pyruvate, though the ability of other $\alpha$-keto acids to replace pyruvate was not tested. This transaminase from $C$. bifermentans shares properties with transaminases from both eukaryotic and prokaryotic cells. These are often oligomeric proteins (frequently dimers or tetramers) which function at high $\mathrm{pH}$, are sensitive to inhibition by carbonyl and thiol reagents and whose reaction mechanisms require pyridoxal phosphate (see review by Braunstein, 1973). Although pyridoxal phosphate is usually bound to the enzyme, there are cases where it is only 
loosely associated and is consequently required for activity. This appears to be the case for the leucine transaminase of $C$. bifermentans reported here.

Decarboxylation of $\alpha \mathrm{kiC}$ to iV was catalysed by a membrane-associated enzyme which contained FAD as an essential component for activity: removal of this group during purification resulted in an inactive apoenzyme whose activity was only partially restored by addition of exogenous FAD. The molar ratio of FAD to protein for the most purified preparation of this enzyme was 0.7 to 1.0 based on a molecular weight of 240000 for the enzyme. Many FADcontaining enzymes are oligomers with one FAD bound per active sub-unit, and frequently contain labile sulphur and sometimes iron (see Singer, 1976). Assuming the $C$. bifermentans enzyme is similar to these, the low ratio of FAD relative to protein is consistent with the low activity associated with the purified enzyme and the observed loss of flavin during purification. Activity was inhibited by thiol reagents including $p$-chloromercuribenzoate, arsenite and iodoacetate. Inhibition by several thiol reagents suggests, at least, the presence of an essential sulphydryl group near the substrate-binding site. Although we failed to detect iron in association with this enzyme, we cannot eliminate the possibility that it is an iron-sulphur protein. Many of the thiol reagents tested (e.g. $p$-chloromercuribenzoate and iodoacetate) react with sulphydryl groups and some (cyanide, especially at high $\mathrm{pH}$, azide and $p$-chloromercuribenzoate) with sulphide of iron-sulphur clusters (Hewitt \& Nicholas, 1963; Lovenberg et al., 1963). Activity was not inhibited by chelating agents (Britz \& Wilkinson, 1982a), but some iron-containing enzymes are not affected by chelating agents. Presumably the FAD is involved with electron transfer associated with decarboxylation but the fate of the reducing power in vivo is not known.

Decarboxylation also required coenzyme A, although ADP and AMP were not essential for activity. Energy generation associated with leucine dissimilation probably occurs via the initial formation of an acyl-coenzyme A derivative which, in vivo, is converted to the acyl-phosphate form which is directly associated with ATP generation (Nisman, 1954). In our assay system, the acyl-coenzyme A derivative may possibly rapidly hydrolyse to form free isovaleric acid, as detected by GLC. Membrane association for this decarboxylase would be convenient for both ATP production and for transfer of reducing power to the membrane-located leucine reductase system.

This work was supported by the National Energy Research Development and Demonstration Committee of Australia. The authors gratefully acknowledge the help of Dr M. J. Playne and the technical assistance of Mr John Wright, both of the Division of Chemical Technology, Commonwealth Scientific and Industrial Research Organization.

\section{REFERENCES}

Bader, J., Rauschehbach, P. \& Simon, H. (1982). On a hitherto unknown fermentation of several amino acids by proteolytic clostridia. FEBS Biochemistry Letters 140, 67-72.

BARKER, H. A. (1961). Fermentation of nitrogenous organic compounds. In The Bacteria, vol. II, Metabolism, pp. 151-207. Edited by I. C. Gunsalus \& R. Y. Stanier. New York: Academic Press.

BARKER, H. A. (1981). Amino acid degradation by anaerobic bacteria. Annual Review of Biochemistry 50, 23-40.

Braunstein, A. E. (1973). Amino group transfer. In The Enzymes, vol. IX, Group Transfer, Part B, pp. 379-481. Edited by P. D. Boyer. New York: Academic Press.

Britz, M. L. \& Wilkinson, R. G. (1982a). Leucine dissimilation to isovaleric and isocaproic acids by cell suspensions of amino acid fermenting anaerobes: the Stickland reaction revisited. Canadian. Journal of Microbiology 28, 291-300.
Britz, M. L. \& Wilkinson, R. G. (1982b). Leucine dissimilation of Clostridium bifermentans: a description of the enzymes synthesizing isovaleric acid. Abstracts, XIII International Congress of Microbiology, p. 140. Washington, D.C.: American Society for Microbiology.

BRITZ, M. L. \& WILKINSON, R. G. (1983). Sub-cellular location of enzymes involved in leucine dissimilation in Clostridium bifermentans. Canadian Journal of Microbiology 29, 441-447.

Bühler, M., Giesel, H., Tischer, W. \& Simon, H. (1980). Occurrence and the possible physiological role of 2-enoate reductases. FEBS Biochemistry Letters 109, 244-246.

ElsDen, S. R. \& Hilton, M. G. (1978). Volatile acid production from threonine, valine, leucine and isoleucine by clostridia. Archives of Microbiology 117 , 165-172.

Hewitt, E. J. \& Nicholas, D. J. D. (1963). Cations and anions: inhibitors and interactions in metabo- 
lism and in enzyme activity. In Metabolic Inhibitors, a Comprehensive Treatise, vol. II, pp. 311-436. Edited by R. M. Hochster \& J. H. Quastel. New York: Academic Press.

Jeng, I. M., Somack, R. \& Barker, H. A. (1974) Ornithine degradation in Clostridium sticklandii; pyridoxal phosphate and coenzyme $\mathbf{A}$ dependent thiolytic cleavage of 2-amino-4-ketopentanoate to alanine and acetylcoenzyme A. Biochemistry 13, 2898-2903.

KozIOL, J. (1971). Fluorimetric analyses of riboflavin and its coenzymes. Methods in Enzymology 18, 253285.

LAEMMLI, U. K. (1970). Cleavage of structural proteins during the assembly of the head of bacteriophage T4. Nature, London 227, 680-685.

LovenberG, W., Buchanan, B. B. \& Rabinowitz, J. C. (1963). Studies on the chemical nature of clostridial ferredoxin. Journal of Biological Chemistry 238, 3899-3913.

Nisman, B. (1954). The Stickland reaction. Bacteriological Reviews 18, 16-42.

Seto, B. \& Stadtman, T. C. (1976). Purification and properties of proline reductase from Clostridium sticklandii. Journal of Biological Chemistry 251, 24352439.
SINGER, T. P. (editor) (1976). Flavins and Flavoproteins. Proceedings of the Fifth International Symposium. Amsterdam: Elsevier Scientific Publishing.

Tanaka, H. \& Stadtman, T. C. (1979). Seleniumdependent clostridial glycine reductase. Purification and characterization of the two membrane-associated protein components. Journal of Biological Chemistry 254, 447-452.

TAYLOR, R. T. \& JENKINS, W. T. (1966). Leucine aminotransferase. 1. Colorimetric assays. Journal of Biological Chemistry 241, 4391-4395.

TuRner, D. C. \& Stadtman, T. C. (1973). Purification of protein components of the clostridial glycine reductase system and characterization of protein $\mathrm{A}$ as a selenoprotein. Archives of Biochemistry and Biophysics 154, 366-381.

WADA, H. \& SNell, E. E. (1961). The enzymatic oxidation of pyridoxine and pyridoxamine phosphates. Journal of Biological Chemistry 236, 20892095.

WEBER, K. \& OSBORN, M. (1969). The reliability of molecular weight determination by dodecyl sulphate polyacrylamide gel electrophoresis. Journal of Biological Chemistry 244, 4406-4412. 